\title{
PERAN LEMBAGA PERADILAN DALAM PEMBATASAN UPAYA HUKUM DALAM PERKARA PERDATA*
}

\author{
Bambang Sugeng Ariadi ${ }^{* *}$, Trisadini P. Usanti***, Johan Wahyudi**** \\ Departemen Hukum Perdata Fakultas Hukum Universitas Airlangga, Surabaya \\ Jalan Dharmawangsa Dalam Selatan, Surabaya, Jawa Timur, 60286
}

\begin{abstract}
In order to application of judicial principle is simple, fast and low cost is to reduce accumulation of cases in the Supreme Court especially at the level of Cassation. Along with the increasing number of incoming cases, and was sentenced in the District Court and Court of Appeal, the amount of the proposed decision legal remedy of Cassation to the Supreme Court also increased and began to be a serious problem. For that we need to do some research on role of Judiciary in Legal action restrictions in order to reduce the accumulation of civil cases.
\end{abstract}

Keywords: judiciary, restriction, legal effort.

\section{Intisari}

Penerapan asas peradilan yang sederhana, cepat dan biaya ringan bertujuan untuk mengurangi penumpukkan perkara di Mahkamah Agung, terutama pada tingkat Kasasi. Seiring dengan makin meningkatnya jumlah perkara yang masuk, dan diputus di PN dan PT, jumlah putusan yang diajukan upaya hukum Kasasi ke MA juga semakin meningkat dan mulai menjadi masalah serius. Untuk itu perlu dilakukan suatu penelitian tentang Peran Lembaga Peradilan dalam Pembatasan Upaya Hukum dalam rangka mengurangi penumpukkan perkara perdata.

Kata Kunci: peradilan, pembatasan, upaya hukum.

\section{Pokok Muatan}

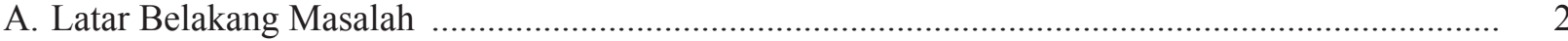

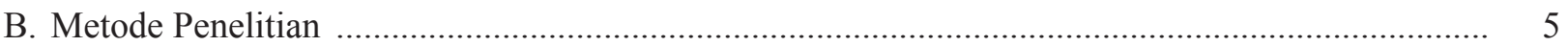

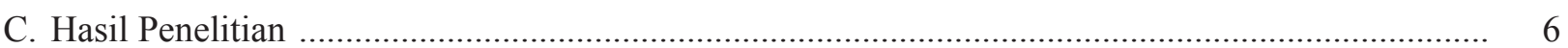

1. Pembatasan Upaya Hukum melalui Lembaga Mediasi di Pengadilan ........................................ 6

2. Pembatasan Upaya Hukum melalui Alasan dan Syarat Berdasarkan Undang-Undang

Nomor 14 Tahun 1985

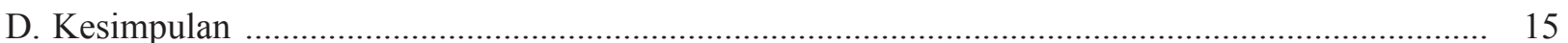

Hasil Penelitian Unggulan Perguruan Tinggi Tahun Anggaran 2015

* Alamat korespondensi: bambangsasfhua@yahoo.com

*** Alamat korespondensi: aditris@ymail.com

***** Alamat korespondensi: jo.fhua99@gmail.com 


\section{A. Latar Belakang Masalah}

Dalam kehidupan bermasyarakat setiap individu selalu mengharapkan untuk hidup damai, dalam artian tidak bermusuhan antara satu dengan yang lainnya, namun jika terjadi suatu permasalahan, diharapkan permusuhan itu dihentikan dalam artian ada perdamaian, yaitu "penghentian permusuhan, permufakatan penghentian permusuhan". ${ }^{1}$ Dengan timbulnya konflik dan masalah ini, maka hukum harus memegang peranan yang penting dalam menyelesaikan masalah dan konflik tersebut. ${ }^{2}$

Penyelesaian perkara perdata dapat dilakukan baik melalui pengadilan (litigasi) maupun diluar pengadilan (non litigasi). Penyelesaian perkara melalui pengadilan dilakukan melalui proses pemeriksaan perkara menurut ketentuan hukum acara perdata. Pihak penggugat mengharapkan adanya suatu putusan pengadilan terhadap perkara yang diajukannya, apabila gugatannya dikabulkan oleh hakim dapat terpenuhi hak-hak keperdataannya secara pasti. Disamping itu, pihak penggugat mengharapkan terhadap putusan hakim yang memenangkan perkaranya sesegera mungkin dapat dimohonkan pelaksanaan eksekusinya, dan dapat pula segera menikmati hasil-hasilnya dalam waktu yang relatif singkat, tanpa harus terlebih dahulu menunggu berlama-lama sampai dengan adanya putusan yang telah memperoleh kekuatan hukum tetap (in kracht van gewijsde).

Namun pada kenyataannya, penyelesaian sengketa melalui pengadilan seringkali terlalu berbelit-belit, memakan waktu dan tidak efisien. Proses pemeriksaan penyelesaian sengketa dengan berperkara di Pengadilan melalui beberapa tahapan, mulai dengan adanya pengajuan gugatan, jawab-menjawab, proses pembuktian, putusan, upaya hukum sampai dilaksanakannya eksekusi, sehingga dapat dikatakan proses pemeriksaannya memerlukan waktu yang relatif lama. Bahkan, apabila pemeriksaan perkara di dua tingkatan peradilan dilalui, maka kadangkala memakan waktu lebih dari 1 (satu) tahun, bahkan bisa sampai 2 (dua) tahun, belum lagi jika ada upaya hukum Kasasi yang kemudian dilanjutkan dengan upaya hukum luar biasa, yaitu, upaya hukum Peninjauan Kembali. Selain itu masih ada kemungkinan akan dilakukan eksekusi, karena jarang sekali ditemui pihak yang kalah, dalam hal ini tergugat, dengan suka rela memenuhi bunyi putusan pengadilan. Eksekusipun dalam pelaksanaannya sering mengalami hambatan dan kesulitan, misalnya, obyek sengketa yang telah berpindah tangan, atau pihak Tergugat yang dikalahkan masih bersikukuh ingin tetap menguasai obyek sengketa, atau adanya penurunan harga dari obyek sengketa yang tidak menentu. Sehingga secara ideal suatu sengketa yang diselesaikan melalui Pengadilan, mulai dari pengajuan gugatan sampai terlaksananya suatu eksekusi, membutuhkan waktu lebih kurang 5 (lima) tahun.

Terkait dengan lamanya proses penyelesaian perkara melalui pengadilan ini sebenarnya bertentangan dengan pelaksanaan asas peradilan yang sederhana, cepat dan biaya ringan sebagaimana ditentukan dalam pasal 2 ayat (4) Undang-Undang No. 48 Tahun 2009 tentang Kekuasaan Kehakiman, yang menyatakan bahwa "Peradilan dilakukan dengan sederhana, cepat, dan biaya ringan." Adanya pengaturan asas peradilan yang sederhana, cepat dan biaya ringan tersebut, hal yang terpenting guna untuk mengurangi penumpukkan perkara di Mahkamah Agung terutama pada tingkat Kasasi. Hal tersebut dikarenakan, seiring dengan makin meningkatnya jumlah perkara yang masuk, dan juga yang berhasil diputus di Pengadilan Negeri dan Pengadilan Tinggi, maka jumlah putusan yang masuk di Mahkamah Agung pada tingkat Kasasi juga meningkat dan mulai menjadi masalah yang serius.

Berdasarkan laporan tahunan Mahkamah Agung RI periode tahun 2009, jumlah perkara yang masuk dari tahun ke tahun terus bertambah. Jika dibandingkan dengan perkara yang masuk ke 
Mahkamah Agung RI tahun 2005 sebanyak 7.468 perkara, maka pada tahun 2009 sebanyak 12.540 perkara, mengalami peningkatan sebesar $67,9 \%{ }^{3}$ Tunggakan perkara hingga Desember 2010 sampai 13.450 perkara, ditambah perkara yang masuk sampai dengan November 2011 sebanyak 11.810 perkara. $^{4}$

Pada tahun 2011, perkara yang ditangani MA mencapai 20.234 perkara yang terdiri atas sisa 2010 sebanyak 8.413 perkara dan yang masuk tahun ini 11.810 perkara. Perkara yang masuk selama periode Januari-November 2011 mencapai 11.810 perkara ini terdiri atas 9.575 perkara kasasi, 2.176 perkara PK, 59 grasi, sedangkan sisa perkara 2010 yang mencapai 8.413 perkara terdiri atas 6.479 perkara kasasi, 1.934 perkara PK dan 10 grasi. Dari seluruh perkara tersebut yang telah berhasil diputus sebanyak 11.671 perkara, yakni putusan kasasi sebanyak 9.357 perkara, Peninjauan Kembali (PK) 2.260 perkara dan grasi 54 perkara. Dengan demikian, sisa perkara yang masih berjalan pada tahun 2011 mencapai 8.563 perkara, yang terdiri atas 6.697 perkara kasasi, 1.851 perkara PK dan 15 grasi. ${ }^{5}$ Sedangkan menurut laporan tahunan MA RI periode tahun 2012 dinyatakan bahwa perkara yang diputus pada 2012 mencapai 10.991, padahal setahun sebelumnya bisa mencapai 13.719 perkara, artinya, ada penurunan produktivitas memutus perkara sekitar 19,88 persen. $^{6}$

Penyebab tunggakan perkara di Mahkamah Agung menurut Harifin A. Tumpa ${ }^{7}$ disebabkan karena hakim tingkat pertama dan banding kurang cermat dalam memutus perkara, sehingga dipertanyakan rasa keadilannya oleh masyarakat sampai ke Mahkamah Agung. Untuk itu diperlukan beberapa tindakan strategis, sebagaimana dikatakan oleh Henry P. Panggabean, sebagai berikut: mengalirnya perkara kasasi setiap tahunnya dipastikan tidak akan mampu diatasi para hakim agung meskipun jumlah melebihi 51 orang. Upaya penanggulangan untuk itu tidak cukup dilakukan melalui pendekatan managemen peradilan tanpa dikaitkan dengan perubahan ketentuan hukum acara serta bantuan pendekatan sistemik terhadap praktek peradilan. ${ }^{8}$

Tunggakan perkara di Mahkamah Agung menimbulkan implikasi pada fungsi Mahkamah Agung yang seharusnya memeriksa kasus-kasus penting yang relevan dengan fungsi menjaga kesatuan penerapan hukum ${ }^{9}$, namun pada saat ini Mahkamah Agung lebih berorientasi pada kuantitas pemutusan tunggakan perkara, sehingga mempengaruhi pada konsistensi putusan. Dengan demikian, tunggakan perkara berdampak pada semakin terdegradasinya fungsi utama Mahkamah Agung sebagai penjaga kesatuan hukum. ${ }^{10}$ Dalam konteks ini, penguatan fungsi peradilan tingkat pertama (PN) dan tingkat II (banding) menjadi penting dalam rangka pembatasan upaya hukum, terkhusus upaya hukum kasasi, sebagai implementasi prinsip peradilan sederhana, cepat dan biaya ringan.

Diberlakukannya sistem kamar di Mahkamah Agung diharapkan proses pemeriksaan dan pemutusan perkara menjadi lebih cepat, selain itu juga diharapkan putusan Mahkamah Agung menjadi lebih konsisten karena untuk permasalahan yang sama diputus majelis hakim yang sama, serta kualitas putusan menjadi lebih maksimal karena suatu perkara bisa diputus oleh mereka yang memang ahli dibidangnya, hal tersebut sesuai dengan SK KMA No. 142/KMA/SK/IX/2011 tertanggal 19 September 2011 tentang Pedoman

\footnotetext{
Mahkamah Agung R.I, "Laporan Tahunan 2009”, http:/www.mahkamahagung.go.id./images/LTMARI-2009.pdf, diakses 25 Oktober 2015. Mahkamah Agung R.I, “Laporan Tahunan 2012”, http:/www.mahkamahagung.go.id./images/LTMARI-2012.pdf, diakses 25 Oktober 2015. Ibid. 
Pelaksanaan sistem kamar di Mahkamah Agung. ${ }^{11}$

Dalam rangka mewujudkan asas peradilan yang sederhana, cepat dan biaya ringan, Mahkamah Agung telah mengeluarkan Surat Edaran Mahkamah Agung Nomor 6 Tahun 1992 tentang Penyelesaian Perkara di Pengadilan Tinggi dan Pengadilan Negeri, yang pada pokoknya agar penyelesaian setiap perkara di pengadilan tidak boleh melampaui tenggang waktu 6 (enam) bulan. Di dalam Surat Edaran Mahkamah Agung Nomor 6 Tahun 1992 tersebut, Mahkamah Agung telah menetapkan batasan waktu atas tahapan proses persidangan, yaitu:

1. Panitera harus menyerahkan berkas perkara kepada ketua pengadilan paling lama 7 (tujuh) hari sejak perkara tersebut didaftar di kepaniteraan.

2. Ketua pengadilan harus menunjuk majelis Hakim yang akan memeriksa perkara tersebut dan harus melimpahkan berkas perkara tersebut kepada majelis Hakim paling lama 7 (tujuh) hari sejak diterimanya berkas perkara tersebut dari panitera.

3. Majelis Hakim yang ditunjuk untuk memeriksa perkara tersebut harus menetapkan hari/tanggal persidangan paling lama 1 (satu) minggu sejak perkara tersebut diterima oleh majelis Hakim. ${ }^{12}$

Selanjutnya, berkenaan dengan asas sederhana, cepat dan biaya ringan, Mahkamah Agung menerbitkan Surat Edaran, Nomor 2 Tahun 1985 tentang Seleksi Terhadap Saksi-Saksi yang Diperintahkan untuk Hadir di Sidang Pengadilan, yang isinya pada pokoknya hendaknya hakim secara bijaksana melakukan seleksi terhadap saksisaksi yang diperintahkan untuk hadir dipersidangan, karena memang tidak ada keharusan bagi hakim untuk memeriksa semua saksi yang ada dalam berkas perkara. Surat edaran ini untuk mengatasi hambatan praktek implementasi asas sederhana, cepat dan biaya ringan.

Berkenaan dengan tenggang waktu penyelesaian perkara di muka pengadilan, ternyata di dalam praktek peradilan, penyelesaian perkara perdata masih melebihi enam (6) bulan, sebagaimana diungkapkan oleh Mahkamah Agung dalam Surat Edaran Mahkamah Agung Nomor: 3 Tahun 1998, tanggal 10 September 1998, tentang Penyelesaian Perkara, bahwa:

Dari hasil pengawasan Pimpinan Mahkamah Agung RI mengenai penyelesaian perkara, yang telah diatur dalam: a. Surat Edaran Mahkamah Agung (SEMA) Nomor 1 Tahun 1962 tentang Cara penyelesaian perkara; b. Surat Edaran Mahkamah Agung (SEMA) Nomor 4 Tahun 1962 tentang Penyelesaian perkara-perkara; c. Surat Edaran Mahkamah Agung (SEMA) Nomor 2 Tahun 1963 tentang Penyelesaian perkara; d. Surat Edaran Mahkamah Agung (SEMA) Nomor 6 Tahun 1992 tentang Penyelesaian perkara di Pengadilan Tinggi dan Pengadilan Negeri; Belum dilaksanakan sebagaimana mestinya. Dalam kenyataannya masih terdapat penyelesaian perkara yang diputus melewati 6 (enam) bulan sebagaimana yang telah ditetapkan dalam Surat Edaran Mahkamah Agung tersebut.

Upaya untuk melaksanakan asas sederhana, cepat dan biaya ringan, dalam proses peradilan dilakukan dengan dikeluarkan Surat Edaran Mahkamah Agung Nomor 1 Tahun 2002, tanggal 30 Januari 2002 tentang Pemberdayaan Pengadilan Tingkat Pertama Menerapkan Lembaga Damai, yang telah diperbaharui dengan dikeluarkannya Peraturan Mahkamah Agung No. (Perma) No. 2 Tahun 2003 tentang Prosedur Mediasi di Pengadilan, sebagaimana kemudian disempurnakan dengan Peraturan Mahkamah Agung (Perma) No. 1 Tahun 2008 tentang Prosedur Mediasi di Pengadilan. Melalui lembaga perdamaian (dading) diharapkan

\footnotetext{
1 Mahkamah Agung RI, “Laporan Tahunan 2012”, http://www.mahkamahagung.go.id./images/LTMARI-2012.pdf, diakses 25 Oktober 2015.

12 Mahkamah Agung RI, 2004, Pedoman Pelaksanaan Tugas dan Administrasi Pengadilan, Buku II, Mahkamah Agung RI, Jakarta, hlm. 104105 .
} 
proses peradilan perdata dapat berlangsung dengan sederhana, cepat dan biaya ringan. Dengan demikian nampak bahwa, Mahkamah Agung melalui Perma No. 1 Tahun 2008 tersebut, mengharapkan adanya penyelesaian sengketa dapat diselesaikan melalui pelembagaan lembaga Mediasi dalam rangka mendukung pelaksanaan asas peradilan yang sederhana, cepat dan biaya ringan tersebut.

Pada mulanya penyelesaian sengketa alternatif diposisikan berhadap-hadapan secara berlawanan atau merupakan pesaing dari penyelesaian sengketa konvensional melalui lembaga peradilan, namun disadari bahwa beberapa model penyelesaian sengketa alternatif dapat diintegrasikan ke Pengadilan (court connected mediation), yaitu untuk mediasi dan konsiliasi. Mengingat kondisi perkara yang menumpuk dan dengan mempertimbangkan kelebihan-kelebihan penyelesaian sengketa alternatif, maka Mahkamah Agung menerbitkan Peraturan Mahkamah Agung No. 1 Tahun 2008 tentang Prosedur Mediasi di Pengadilan, yang bertujuan untuk pelembagaan lembaga mediasi di pengadilan.

Berdasarkan uraian di atas, maka rumusan masalah yang hendak dibahas dalam penulisan ini adalah: Pertama, pembatasan upaya hukum melalui lembaga mediasi di pengadilan; dan Kedua, pembatasan upaya hukum melalui alasan dan syarat berdasarkan ketentuan Undang-Undang Nomor 14 Tahun 1985.

\section{B. Metode Penelitian \\ 1. Tipe Penelitian}

Menurut Peter Mahmud Marzuki ${ }^{13}$, dilihat dari segi keilmuan hukum yang bersifat preskriptif maka tipe penelitian dasar (fundamental research) berada diluar penelitian hukum, karena obyek kajiannya adalah masalah hukum sebagai gejala social bukan hukum sebagainorma social. Sedangkan doctrinal research, reform-oriented research, dan theoretical research merupakan penelitian hukum, karena memiliki karakter tersendiri yang tujuannya untuk mendapatkan pemahaman yang lebih dalam mengenai gejala hokum tertentu. ${ }^{14}$

Sesuai dengan isu hukum yang telah ditetapkan dalam penelitian ini, maka tipe penelitian ini merupakan penelitian hukum (legal research), yaitu, suatu proses untuk menemukan aturan hukum, prinsip-prinsip hukum, maupun doktrindoktrin hukum, menjaab isu hukum yang dihadapi. ${ }^{15}$ Penelitian hukum ini dilakukan untuk menghasilkan argumentasi, teori atau konsep baru sebagai preskripsi dalam menyelesaikan masalah yang dihadapi ${ }^{16}$, atau mengikuti pendapat Terry Hutchingson, merupakan penelitian hukum dengan tipe reform-oriented research.

\section{Pendekatan Masalah}

Berdasarkan pada isu hukum yang telah ditetapkan dan tujuan penelitian yang diinginkan maka pendekatan yang digunakan adalah:

a. Pendekatan undang-undang (statute approach), yaitu, menelaah semua undang-undang dan peraturan lain dalam bidang hukum acara perdata yang bersangkut dengan isu hukum dengan maksud untuk mencari ratio legis dan dasar antologis lahirnya undang-undang sehingga mampu mengangkat kandungan filosofis serta mempelajari konsistensi antara undang-undang dengan peraturan perundangan yang lainnya.

b. Pendekatan konseptual (conceptual approach), yaitu, pendekatan yang beranjak dari pandangan-pandangan dan doktrin-doktrin yang berkembang di dalam ilmu hukum, khususnya hukum acara perdata, sehingga dapat menemukan ide-ide yang melahirkan pengertian-pengertian hukum, konsepkonsep hukum, dan asas-asas hukum

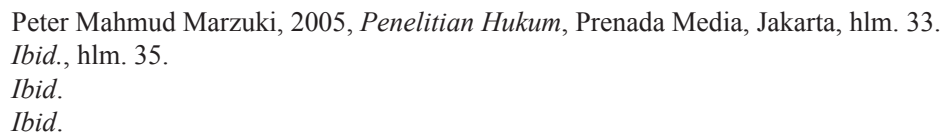


yang relevan dengan isu hukum sehingga mampu membangun suatu argumentasi hukum dalam memecahkan isu hukum.

c. Pendekatan kasus (case appproach), yaitu, menelaah kasus-kasus yang diputus oleh pengadilan berkaitan dengan isu yang dihadapi. Dalam pendekatan ini, yang akan ditelaah adalah ratio decidendi atau legal reasoning, yaitu, pertimbangan hakim untuk sampai kepada suatu putusan yang menjadi referensi dalam penyusunan argumentasi hukum dalam pemecahan isu hukum.

\section{Sumber Bahan Hukum}

Tipe penelitian hukum ini merupakan penelitian yang berbasis kepustakaan (library based), yang berfokus pada analisis bahan hukum primer dan sekunder. Bahan hukum primer adalah sumber aktual dari hukum, yaitu, undang-undang dan putusan pengadilan (the primary materials are the actual sources of the law - the legislation and case law), ${ }^{17}$ dalam hal ini antara lain: peraturan perundang-undangan, yaitu: HIR, RBG, RV, BW, dan peraturan yang berkaitan dengan hukum acara perdata serta Rancangan Undang-Undang Hukum Acara Perdata serta yurisprudensi Mahkamah Agung RI Sedangkan bahan hukum sekunder, adalah bahan yang meliputi komentar pada hukum yang ditemukan pada buku dan jurnal hukum (the secondary materials include he commentary on the law found in texbooks and legal journal), ${ }^{18}$ dalam hal ini antara lain: buku-buku teks, kamus-kamus hukum, jurnal-jurnal hukum.

\section{Prosedur Pengumpulan Bahan Hukum}

Bahan hukum baik primer maupun sekunder diperoleh akan diinventarisasi dan diidentifikasi untuk selanjutnya dipergunakan dalam menganalisis permasalahan yang berhubungan dengan kajian penelitian ini. Dalam melakukan inventarisasi serta identifikasi bahan hukum digunakan sistem kartu (card system) yaitu dengan mengurutkan bahan-bahan hukum sebagai sumbernya, sehingga penatalaksanaan secara kritis, logis dan sistematis yang kemudian dilakukan analisis secara mendalam (in depth) atas fakta-fakta hukum hukum yang ditemukan. Dengan langkah-langkah demikian diharapkan akan lebih mempermudah alur penyesuaian penelitian ini. Setelah melalui tahapantahapan inventarisasi dan identifikasi terhadap sumber bahan hukum yang relevan (primer dan sekunder), langkah berikutnya melakukan sistematisasi keseluruhan bahan hukum yang ada. Proses sistematisasi ini juga diberlakukan terhadap teori-teori, konsep-konsep, doktrin serta bahan rujukan lainnya. Rangkaian tahapan inventarisasi, identifikasi dan sistematisasi tersebut dimaksudkan untuk mempermudah pengkajian dari permasalahan penelitian.

\section{Analisis Bahan Hukum}

Analisis bahan hukum dalam penelitian ini, diawali: Pertama, melakukan identifikasi terhadap fakta-fakta hukum untuk menetapkan isu hukum yang hendak dipecahkan; Kedua, mengumpulkan bahan-bahan hukum (primer dan sekunder); Ketiga, melakukan telaah atas isu hukum yang diajukan berdasarkan bahan-bahan hukum yang telah dikumpulkan; Keempat, merumuskan kesimpulan dalam bentuk argumentasi menjawab isu hukum; dan Kelima, memberikan preskripsi berdasarkan kesimpulan. ${ }^{19}$

\section{Hasil Penelitian}

\section{Pembatasan Upaya Hukum melalui Lembaga Mediasi di Pengadilan}

Didorong oleh menumpuknya beban perkara di pengadilan serta untuk memberikan akses yang luas kepada masyarakat untuk memperoleh keadilan dan penyelesaian yang memuaskan atas sengketa yang mereka hadapi, maka Mahkamah Agung (MA) telah menerbitkan Peraturan Mahkamah Agung

\footnotetext{
Terry Hutchinson, 2002, Resarching and Writing in Law, National Library of Australia, Sydney, hlm. 9.

Terry Hutchinson, Loc.cit.

Peter Mahmud Marzuki, Op.cit., hlm. 171.
} 
No. 1 Tahun 2008 tentang Prosedur Mediasi di Pengadilan (Perma No. 1 Tahun 2008). Perma No. 1 Tahun 2008 ini merupakan revisi dari dari Peraturan Mahkamah Agung No. 2 Tahun 2003 dalam Menerapkan Lembaga Damai yang merupakan pelaksanaan dari Pasal $130 \mathrm{HIR} / 154 \mathrm{RBg}$, dimana menurut ketentuan tersebut hakim dalam perkara perdata wajib menganjurkan para pihak dalam sidang pertama untuk menempuh perdamaian.

Mediasi dalam rangka Perma No. 1 Tahun 2008 bersifat wajib ditempuh dalam perkara perdata yang diajukan ke pengadilan pada tingkat pertama atau di pengadilan negeri, demikian Pasal 2 ayat (2) Perma No. 1 Tahun 2008 menegaskan. Oleh karena itu, sifat dari mediasi di pengadilan ini adalah bersifat mandatory, para pihak tidak bisa menolak ataupun untuk meminta langsung dilakukannya pemeriksaan perkara secara litigasi kepada majelis hakim yang memeriksa perkara itu. Lebih lanjut, dalam Pasal 2 ayat (3) Perma No. 1 Tahun 2008 ditentukan bahwa apabila ada perkara yang diperiksa dan diputus tidak menempuh prosedur mediasi berdasarkan peraturan ini merupakan pelanggaran terhadap ketentuan Pasal 130 HIR dan atau Pasal 154 Rbg yang mengakibatkan putusan batal demi hukum.

Pada tahap pra mediasi, pada sidang pertama yang dihadiri penggugat dan tergugat atau kuasa hukumnya, hakim mewajibkan para pihak untuk terlebih dahulu menempuh mediasi. ${ }^{20}$ Hakim mewajibkan para pihak pada hari itu juga atau paling lama 2 (dua) hari kerja berikutnya untuk berunding guna memilih mediator baik yang ada di dalam daftar yang dimiliki oleh pengadilan ataupun di luar daftar pengadilan, termasuk biaya yang mungkin timbul akibat pilihan penggunaan mediator bukan hakim). ${ }^{21}$ Mediator yang dipilih bisa dari kalangan hakim, asalkan bukan hakim yang memeriksa perkara tersebut, ataupun mediator dari kalangan non-hakim dengan syarat telah memiliki sertifikat sebagai mediator yang telah diakreditasi oleh MA.22

Pelaksanaan mediasi dapat diselenggarakan di salah satu ruang pengadilan dan untuk penggunaan ruangan ini tidak dikenakan biaya, sedangkan apabila pelaksanaan mediasi dilakukan di tempat lain, maka biaya yang timbul dari penggunaan tempat tersebut dibebankan kepada para pihak berdasarkan kesepakatan. Demikian pula penggunaan mediator hakim tidak dikenakan biaya sedangkan untuk mediator bukan hakim biayanya ditanggung oleh para pihak berdasarkan kesepakatan. ${ }^{23}$

Tahap mediasi dimulai lima hari kerja setelah pemilihan atau penunjukan mediator, para pihak wajib menyerahkan resume perkara kepada satu sama lain dan kepada mediator. ${ }^{24}$ Proses mediasi berlangsung selama empat puluh hari kerja sejak mediator dipilih oleh para pihak atau ditunjuk oleh ketua majelis hakim ${ }^{25}$ dan atas dasar kesepakatan para pihak, jangka waktu mediasi dapat diperpanjang paling lama 14 (empat belas) hari kerja sejak berakhir masa 40 (empat puluh) hari sebagaimana dimaksud dalam ayat (3). ${ }^{26}$ Dalam pelaksanaan mediasi para pihak ataupun kuasa hukumnya dan mediator dapat mengundang saksi ahli dalam bidang tertentu untuk memberikan penjelasan ataupun pertimbangan terkait dengan penyelesaian sengketa, dimana segala biaya pemanggilan saksi ahli ini dibebankan kepada para pihak.

Baik dicapai kesepakatan ataupun tidak, hasil dari mediasi tetap dibawa ke pengadilan dan para pihak menghadap kembali kepada mejelis hakim. Apabila dicapai kesepakatan maka kesepakatan tersebut harus dirumuskan secara tertulis serta ditandatangani para pihak dan mediator memeriksa kembali kesepakatan tersebut untuk menghindari adanya kesepakatan yang saling bertentangan. Atas kesepakatan yang telah dicapai berdasarkan 
permintaan para pihak, hakim dapat mengukuhkan kesepakatan itu sebagai akta perdamaian (akta van dading) yang memiliki kekuatan hukum tetap, dan sebaliknya apabila para pihak tidak menghendaki dikukuhkannya kesepakatan itu dalam akta perdamaian, maka dalam kesepakatan tertulis itu harus terdapat klausula yang memuat pernyataan pencabutan perkara. ${ }^{27}$

Apabila tidak tercapai kesepakatan dalam mediasi hingga batas waktu yang ditentukan, mediator wajib menyatakan bahwa proses mediasi gagal dan memberitahukannya kepada Majelis Hakim yang memeriksa perkara. Segera setelah pemberitahuan itu hakim melanjutkan proses pemeriksaan perkara sesuai dengan ketentuan dalam Hukum Acara Perdata yang berlaku sebagaimana Pasal 18 Perma No. 1 Tahun 2008. Apabila mediasi gagal mencapai kesepakatan dan proses pemeriksaan perkara di persidangan dilanjutkan kembali, maka segala pernyataan dan pengakuan para pihak dalam proses mediasi tidak dapat digunakan dalam proses persidangan yang bersangkutan atau perkara lainnya. Demikian pula fotokopi dokumen, notulen dan catatan mediator wajib dimusnahkan dan mediator tiodak dapat diminta untuk menjadi saksi dalam persidangan perkara yang bersangkutan.

Dari hasil pengumpulan data yang diperoleh dari Pengadilan Negeri Surabaya terhitung semenjak Perma No. 1 Tahun 2008 disahkan (11 September 2003) sampai dengan November 2004 tercatat sebanyak 115 perkara gugatan perdata didaftarkan dan kemudian menempuh mediasi dan yang mencapai kesepakatan damai dari proses mediasi dalam rangka Perma No. 1 Tahun 2008 hanya $0,87 \%{ }^{28}$ Berdasarkan data tersebut, dari tahapan mediasi yang berhasil, hampir lebih dari $99 \%$ perkara (kecuali perceraian, karena gugatan perceraian dapat diputus verstek) yang didominasi oleh perkara dengan dasar gugatan PMH (Perbuatan Melanggar Hukum) berlanjut proses pemeriksaannya atau dengan kata lain proses mediasi gagal, dan perkara berlanjut dengan mengajukan banding atau upaya hukum lainnya. ${ }^{29}$

Demikian pula dalam periode yang sama pada Pengadilan Negeri Jakarta Pusat dari 505 perkara gugatan perdata yang didaftarkan dan kemudian menempuh mediasi, hanya 9 perkara saja yang berhasil mencapai kesepakatan damai melalui mediasi atau hanya $1,78 \% .{ }^{30}$ Melihat angka-angka tersebut dapat dikatakan bahwa tingkat keberhasilan proses mediasi pada dua pengadilan yang dijadikan sampel data masih sangat rendah.

Tidak dapat dipungkiri bahwa mediasi dalam rangka Perma No. 1 Tahun 2008 merupakan suatu terobosan yang patut diapresiasi dalam rangka upaya untuk mengurangi beban perkara yang harus diselesaikan oleh pengadilan maupun untuk memberi akses masyarakat dalam memperoleh keadilan serta penyelesaian sengketa yang memuaskan para pihak. Namun demikian beberapa kendala ditemui dalam penerapan Perma No. 1 Tahun 2008, yaitu:

\section{a. Faktor Kendala dari Ketentuan Perma No. 1 Tahun 2008}

Sebagaimana dikatakan bahwa Perma No. 1 Tahun 2008 menentukan bahwa para pihak dalam gugatan perdata wajib menempuh terlebih dahulu mediasi sebelum proses litigasi dilanjutkan. Dalam Pasal 2 ayat (1) dinyatakan: Semua perkara perdata yang diajukan ke pengadilan tingkat pertama wajib untuk lebih dahulu diselesaikan melalui perdamaian dengan bantuan mediator. Ketentuan ini secara substansial tidak sesuai dengan asas penyelesaian sengketa alternatif maupun asas mediasi dan semangat yang dikandung dalam Pasal $130 \mathrm{HIR} / 154 \mathrm{RBg}$ yang hendak dilaksanakan oleh Peraturan

\footnotetext{
Pasal 17 Peraturan Mahkamah Agung Nomor 1 Tahun 2008 tentang Prosedur Mediasi di Pengadilan

Pasal 19 Peraturan Mahkamah Agung Nomor 1 Tahun 2008 tentang Prosedur Mediasi di Pengadilan.

Daftar Perkara PN Surabaya tahun 2003 dan 2004

Salah seorang Hakim PN Surabaya, wawancara bulan Juni 2015.

Daftar Perkara PN Jakarta Pusat tahun 2003 dan 2004.
} 
Mahkamah Agung ini. ${ }^{32}$ Menurut Perma No.

1 Tahun 2008 para pihak yang berperkara diwajibkan untuk menempuh mediasi, maka dalam hal ini telah melanggar prinsip dari penyelesaian sengketa alteranatif termasuk prinsip mediasi itu sendiri yaitu prinsip kesukarelaan (voluntary) dan prinsip sesuai kehendak sendiri (self-determination). Sebagaimana dinyatakan dalam American Bar Association Model Standards of Conduct for Mediators.

Self-determination: a mediator shall recognize that mediation is based on the principle of self-determintion by the parties.

Self-determination is the fundamental principle of mediation. It requires that the mediation process rely upon ability of the parties to reach a voluntary, uncoerced agreement. Any party may withdraw from mediation at any time..$^{33}$

Demikian halnya ketentuan Pasal 2 ayat (2) Perma No. 1 Tahun 2008 tidak sesuai dengan semangat dari Pasal 130 HIR/154 $\mathrm{RBg}$ dimana pasal tersebut menghendaki hakimlah yang seharusnya mendamaikan para pihak, karena memang dalam beberapa hal hakim dalam perkara perdata tidak sepenuhnya pasif, ia secara aktif dapat mendamaikan para pihak. ${ }^{34}$ Dengan adanya Perma No. 1 Tahun 2008, maka peran hakim itu telah diambil alih oleh peran mediator. Berarti dalam hal ini terjadi pengalihan tugas dan wewenang mendamaikan dari hakim kepada mediator.

Dalam Pasal 11 Perma No. 1 Tahun 2008 yang mengatur mengenai tata cara pemilihan atau penunjukan hakim dinyatakan demikian:

1) Setelah para pihak hadir pada hari sidang pertama, hakim mewajibkan para pihak pada hari itu juga atau paling lama 2 (dua) hari kerja berikutnya untuk berunding guna memilih mediator termasuk biaya yang mungkin timbul akibat pilihan penggunaan mediator bukan hakim.

2) Parapihak segeramenyampaikan mediator pilihan mereka kepada ketua majelis hakim.

3) Ketua majelis hakim segera memberitahu mediator terpilih untuk melaksanakan tugas.

4) Jika setelah jangka waktu maksimal sebagaimana dimaksud ayat (1) terpenuhi, para pihak tidak dapat bersepakat memilih mediator yang dikehendaki, maka para pihak wajib menyampaikan kegagalan mereka memilih mediator kepada ketua majelis hakim.

5) Setelah menerima pemberitahuan para pihak tentang kegagalan memilih mediator, ketua majelis hakim segera menunjuk hakim bukan pemeriksa pokok perkara yang bersertifikat pada pengadilan yang sama untuk menjalankan fungsi mediator.

6) Jika pada pengadilan yang sama tidak terdapat hakim bukan pemeriksa perkara yang bersertifikat, maka hakim pemeriksa pokok perkara dengan atau tanpa sertifikat yang ditunjuk oleh ketua majelis hakim wajib menjalankan fungsi mediator.

Dengan demikian ketentuan dalam Pasal 11 Perma No. 1 Tahun 2008 ini mengandung arti bahwa:

1. Personal mediator yang dapat dipilih sudah tertentu, yaitu mediator yang terdapat dalam daftar pengadilan dan di luar daftar pengadilan;

2. Kepada para pihak, pada tahap

\footnotetext{
32 Otto Hasibuan, "Problematik Mediasi dalam Praktek Pengadilan Dihubungkan dengan Perma No. 1 Tahun 2008 tentang Prosedur Mediasi di Pengadilan, Makalah, disampaikan dalam Launching Magister Hukum Minat Studi Peradilan Fakultas Hukum Universitas Airlangga dan Sosialisasi Perma No. 1 Tahun 2008, Surabaya, 14 Februari 2004.

33 Martindale-Hubbell, 1999, International Arbitration and Dispute Resolution Directory, Cavendish Publishing Limited, London, hlm. 319.

34 R. Supomo, 1971, Hukum Atjara Perdata Pengadilan Negeri, Pradnja Paramita, Djakarta, hlm. 17-19.
} 
pertama diberikan kesempatan untuk memilih daftar mediator yang dimiliki oleh pengadilan atau di luar daftar mediator yang dimiliki oleh pengadilan, kalau tidak berhasil wajib memilih dari daftar pengadilan, apabila masih belum juga menentukan pilihan, maka Hakim Ketua Majelis akan menunjuk seorang mediator dengan penetapan.

Hal ini menimbulkan permasalahan, apabila para pihak memang sepakat berdamai dengan menggunakan jasa mediator, tentunya mereka berhak pula dengan bebas memilih siapa yang menjadi mediator, namun dengan adanya ketentuan dalam Pasal 11 ayat (5) Perma No. 1 Tahun 2008, maka dalam hal ini sekali lagi ada paksaan untuk menerima mediator yang ditunjuk oleh Hakim Ketua Mejelis melalui suatu penetapan dan ini adalah suatu bentuk dari pelanggaran prinsip self determination para pihak dalam menentukan mediator yang akan memimpin proses mediasi.

Adanya ketidaksesuaian prinsip dalam Perma No. 1 Tahun 2008 yang sebagaimana mestinya diterapkan dalam setiap pelaksanaan mediasi berakibat lebih lanjut pada tidak efektifnya pelaksanaan mediasi di lapangan. Para pihak yang berperkara di pengadilan sejak semula memang sudah bermusuhan secara psikologis sudah saling "membenci" satu sama lain, dan hanya satu tujuan mereka dalam berperkara di pengadilan, yaitu saling membuktikan kesalahan pihak lawan dan berusaha untuk mendapatkan putusan yang memenangkan dirinya serta sedapat mungkin putusan itu menghukum pihak lawan dengan seberat-beratnya. Untuk itu upaya mediasi di pengadilan sejak semula memang sangat sulit untuk dicapai keberhasilannya.

Para pihak melaksanakan mediasi dalam rangka Perma No. 1 Tahun 2008 dalam suasana keterpaksaan. Dalam keterpaksaan itu para pihak tidak sungguh-sungguh untuk mencapai kesepakatan penyelesaian, mereka hanya secara formalitas saja menjalankan mediasi hingga jangka waktu yang ditentukan dalam ketentuan Perma No. 1 Tahun 2008 berakhir dan mereka kemudian menghadap kembali dalam persidangan untuk melanjutkan pemeriksaan perkara dalam persidangan. Tentunya kondisi demikian ini berakibat bertambahlamanya penyelesaian sengketa yang kemudian tentunya mengakibatkan peningkatan biaya yang harus dikeluarkan, terutama apabila menggunakan jasa advokat.

Kendala lain yang berkaitan dengan ketentuan-ketentuan dalam Perma No. 1 Tahun 2008 adalah mengenai jangka waktu proses mediasi paling lama empat puluh hari kerja, dan atas dasar kesepakatan para pihak dapat diperpanjang selama empat belas hari kerja, sebagaimana dinyatakan dalam Pasal 13 ayat (3) dan (4) Perma No. 1 Tahun 2008. Permasalahan yang muncul dengan adanya ketentuan ini adalah bahwa apabila para pihak tidak menunjukkan kesungguhannya untuk menempuh proses mediasi, sehingga proses mediasi dijalankan tidak secara maksimal hanya untuk memenuhi persyaratan formil yang diwajibkan, maka jangka waktu tersebut justru memperlambat proses penyelesaian sengketa. Hendaknya dalam hal ini mediator diberikan kewenangan, dengan memperhatikan dan mempertimbangkan ketidaksungguhan dari para pihak untuk menempuh proses mediasi, untuk menyatakan mediasi gagal meskipun jangka waktu yang diberikan belum berakhir sehingga proses persidangan dapat segera dilanjutkan.

Demikian pula apabila para pihak telah menunjukkan kemauan dan kesungguhan dalam menempuh proses mediasi, serta telah ada suatu kesepakatan awal yang konstruktif namun belum mencapai kesepakatan final sedangkan jangka waktu mediasi yang 
diberikan Perma No. 1 Tahun 2008 telah berakhir, maka kiranya ketentuan ini juga kurang tepat. Alangkah baiknya apabila dalam kondisi seperti ini mediator diberikan kewenangan apabila jangka waktu telah berakhir sedangkan para pihak telah mencapai suatu kesepakatan konstruktif namun belum final sehingga masih memerlukan tambahan waktu lagi untuk menghadap kepada majelis hakim yang memeriksa perkara untuk memohon perpanjangan waktu. majelis hakim hendaknya mendengar dan mempertimbangkan dengan seksama alasanalasan yang dimohonkan oleh mediator tersebut.

\section{b. Kendala Penerapan dalam Praktek}

Selain kendala-kendala yang diakibatkan oleh ketentuan-ketentuan dari Perma No. 1 Tahun 2008 yang tidak sesuai dengan prinsip-prinsip penyelesaian sengketa alternatif sehingga berakibat pada kurang efektifnya pelaksanaan mediasi terdapat pula kendala-kendala penerapan di lapangan. Perma No. 1 Tahun 2008 memungkinkan penggunaan mediator hakim pada pengadilan yang bersangkutan dengan syarat bahwa hakim tersebut tidaklah sebagai hakim yang memeriksa perkara yang sedang berusaha dimediasikan itu. Beberapa praktisi mengemukakan keberatannya atas adanya hakim yang menjadi mediator, keberatan ini cukup beralasan dikarenakan hakim yang dalam pekerjaannya adalah memeriksa, mengadili dan memutus perkara sekarang diharuskan untuk menjadi mediator yang memerlukan kepiawaian dalam memfasilitasi perundingan, sedangkan Perma No. 1 Tahun 2008 tidak menyaratkan hakim yang menjadi mediator terlebih dahulu untuk mengikuti pelatihan mediator. Akibatnya terdapat kemungkinan yang cukup besar bahwa proses mediasi yang dipimpin oleh mediator hakim mengalami kegagalan. Kendala di atas juga berkaitan erat dengan masih terbatasnya jumlah mediator profesional yang telah menempuh pendidikan mediator terutama di daerah-daerah terpencil, sehingga jumlah pilihan mediatornya pun sangat kurang, terpaksalah para pihak menjatuhkan pilihan pada mediator hakim.

Kendala yang lain berkaitan dengan peranan advokat sebagai kuasa hukum dari pihak-pihak yang bersengketa. Sebagaimana diketahui honorarium advokat dalam menangani suatu perkara dari kliennya dapat didasarkan pada rumitnya dan/atau lamanya penyelesaian sengketa itu berlangsung. Hal ini berakibat dukungan advokat untuk menyelesaikan sengketa melalui mediasi dalam rangka Perma No. 1 Tahun 2008 kurang. Para advokat banyak berpikir bahwa lebih baik penyelesaian sengketa dilanjutkan di persidangan pengadilan yang lebih lama prosesnya daripada diselesaikan lebih cepat melalui mediasi, satu dan lain hal dikarenakan honorarium perkara yang akan ia terima dari kliennya.

Kendala mengenai peranan advokat ini juga didukung oleh pandangan sebagian hakim bahwa kehadiran advokat dalam mediasi seringkali malah menghambat proses mediasi dan tidak mendukung bagi proses mediasi yang konstruktif. Di lain pihak para advokat sebagai kuasa hukum berpendapat bahwa sebelum perkara didaftarkan sebagai gugatan di pengadilan para pihak telah menempuh upaya damai dalam suatu perundingan tanpa bantuan pihak ketiga (negosiasi), sehingga apabila kemudian mereka harus menempuh lagi perdamaian melalui proses mediasi dalam rangka Perma No. 1 Tahun 2008 adalah sia-sia belaka.

Masalah tempat pelaksanaan mediasi juga menjadi kendala tersendiri. Sebagaimana diatur dalam Perma No. 1 Tahun 2008 bahwa pelaksanaan mediasi dapat dilakukan di salah satu ruangan pengadilan dan untuk itu para pihak dibebaskan dari biaya penggunaan 
ruangan. Namun, sekali lagi terutama di daerah-daerah terpencil terdapat kendala penyediaan sarana dan prasarana ruangan mediasi di pengadilan sehingga ruangan yang mediasi yang disediakan di pengadilan kurang representatif.

Mengingat kendala-kendala yang demikian banyaknya dalam pelaksanaan mediasi di pengadilan, maka untuk mengefektifkan proses mediasi di pengadilan ini dirasa perlu peranan yang lebih besar lagi dari mediator dalam menjalankan proses mediasi. Beberapa kasus yang berhasil dimediasi menunjukkan peranan mediator yang cukup besar terutama dalam memberikan pemahaman kepada para pihak yang bersengketa akan pentingnya proses mediasi untuk menyelesaiakan sengketa melalui kesepakatan yang menguntungkan bagi pihak-pihak yang bersengketa.

Dengan demikian jelas bahwa keterpaksaan pihak-pihak yang bersengketa untuk menempuh mediasi wajib dalam rangka Perma No. 1 Tahun 2008 dapat direduksi dengan pemahaman yang baik mengenai pentingnya dan manfaatnya proses mediasi ini ditempuh dan untuk itu peranan mediator untuk memberikan pemahaman (edukasi) mengenai hal tersebut sangatlah penting.

\section{Pembatasan Upaya Hukum melalui Alasan dan Syarat Berdasarkan Undang-Undang Nomor 14 Tahun 1985}

Penumpukkan perkara di Mahkamah Agung disebabkan oleh pengaturan pembatasan perkara yang ada saat ini dianggap masih kurang lengkap dan tidak mampu menahan besarnya keinginan pencari keadilan untuk meminta keadilan ke pengadilan tertinggi tersebut. Secara umum telah diatur alasanalasan yang memungkinkan putusan atau penetapan pengadilan tingkat bawah diajukan upaya hukum
Kasasi, yaitu di dalam Pasal 30 Undang-Undang Nomor 14 Tahun 1985, yang menyatakan bahwa dalam tingkat kasasi Mahkamah Agung dapat membatalkan putusan atau penetapan pengadilan tingkat bawah karena:

a) Tidak berwenang atau melampaui batas wewenang;

b) Salah menerapkan atau melanggar hukum;

c) Lalai memenuhi syarat-syarat yang diwajibkan oleh peraturan perundangundangan yang mengancam kelalaian itu dengan batalnya putusan tersebut.

Selanjutnya, dalam perkara perdata untuk alasan pengajuan upaya hukum Peninjauan Kembali, yakni hanya dalam hal: ${ }^{35}$

a. Putusan didasarkan pada kebohongan/ tipu muslihat yang diketahui setelah perkaranya

b. Diputus atau didasarkan pada bukti yang kemudian oleh hakim pidana dinyatakan palsu;

c. Ditemukan bukti yang menentukan yang pada waktu perkara diperiksa tidak ditemukan;

d. Dikabulkan hal yang tidak dituntut atau lebih yang dituntut;

e. Ada tuntutan belum diputus tanpa pertimbangan;

f. Adanya putusan yang bertentangan terhadap pihak yang sama mengenai suatu soal yang sama;

g. Atas dasar yang sama oleh pengadilan yang sama atau sama tingkatnya;

h. Terdapat kekhilafan hakim atau kekeliruan yang nyata dalam putusan.

Dengan demikian, dalam konteks perkara perdata, praktis dapat dikatakan hampir tidak ada jenis perkara atau putusan tertentu yang tidak dapat diajukan upaya hukum Kasasi atau Peninjauan Kembali selama terpenuhinya alasan-alasan sebagaimana tersebut di atas. ${ }^{36}$ Selain itu, ada pengaturan tentang persyaratan yang harus dipenuhi

Lihat Pasal 67 UU No. 14 Tahun 1985, Pasal 132 UU No. 5 Tahun 1986, Pasal 24 UU No. 48 Tahun 2009 (Lembaran Negara Republik Indonesia Tahun 1985 Nomor 73, Tambahan Lembaran Negara Republik Indonesia Nomor 3316 Tahun 1985).

36 Sebenarnya pembatasan perkara kasasi perdata pernah diatur dalam Undang-undang No. 20 tahun 1947 tentang Pengadilan Peradilan Ulangan, dimana dalam Pasal 6 dikatakan bahwa perkara perdata dengan nilai kurang dari Rp. 100 tidak dapat diajukan banding ke pengadilan tinggi. Namun karena kondisi Negara pada saat itu, UU tersebut tidak pernah belaku efektif. 
oleh pihak-pihak yang ingin perkaranya dapat diajukan upaya hukum kasasi, yang secara tidak langsung juga dapat membatasi jumlah perkara yang masuk ke Mahkamah Agung, sebagaimana ditentukan dalam Pasal 44 Undang-Undang Nomor 14 Tahun 1985, yang mengatur bahwa "Kasasi dalam perkara perdata, agama dan tata usaha negara hanya dapat diajukan oleh pihak yang berperkara atau wakilnya yang secara khusus dikuasakan untuk itu".

Selain itu, masih banyak lagi pengaturan dalam undang-undang, ketentuan internal Mahkamah Agung atau putusan Mahkamah Agung yang mengatur pula kapan suatu perkara dapat diajukan kasasi atau Peninjauan Kembali ${ }^{37}$, suratsurat yang perlu lampirkan dalam pengajuannya, ke mana pengajuan diajukan ${ }^{38}$, dan formalitasformalitas pengajuan kasasi dan Peninjauan Kembali lainnya, yang jika dilanggar atau tidak dipenuhi mengakibatkan permohonan tersebut tidak dapat diterima. ${ }^{39}$

Dalam prakteknya, terutama pada masa lalu, permohonan kasasi yang sebenarnya tidak memenuhi syarat formal sebagai dimaksud Pasal 46 dan 47 Undang-Undang Nomor 14 Tahun 1985 sebagaimana dijelaskan di atas tetap harus diterima (didaftar) untuk diputus oleh Mahkamah Agung. Hal ini mengakibatkan semakin menumpuknya perkara kasasi di Mahkamah Agung. ${ }^{40}$ Oleh karena itu, Mahkamah Agung menerbitkan Peraturan Mahkamah Agung (PERMA) Nomor 1 Tahun 2001 tentang Permohonan Kasasi Perkara Perdata Yang Tidak Memenuhi Persyaratan Formal. Adapun yang dimasud dengan persyaratan formal adalah persyaratan yang wajib dipenuhi oleh pemohon kasasi dalam mengajukan permohonan kasasi sebagaimana diatur dalam Pasal 46 dan Pasal 47 Undang-Undang Nomor 14 Tahun 1985 tentang Mahkamah Agung ${ }^{41}$, misalnya, mengenai jangka waktu pengajuan kasasi dan pengirimkan memori kasasi atau kewajiban mengirimkan memori kasasi. Dalam PERMA tersebut ditegaskan bahwa panitera pada Pengadilan Tingkat Pertama yang memutus perkara yang dimohonkan kasasi tidak perlu meneruskan permohonan tersebut kepada Mahkamah Agung. ${ }^{42}$ Selanjutnya, substansi Peraturan Mahkamah Agung (Perma) Nomor 1 Tahun 2001 ini kemudian diadopsi di dalam Undang-Undang Nomor 5 Tahun 2004 tentang Perubahan Atas Undang-Undang Nomor 14 Tahun 1985 tentang Mahkamah Agung. ${ }^{43}$

Di dalam memori kasasi harus dimuat keberatan-keberatan atau alasan-alasan kasasi yang berhubungan dengan pokok persoalan perkara, sebagaimana ditentukan dalam Pasal 30 UndangUndang Nomor 14 Tahun 1985. Berdasarkan alasanalasan tersebut di atas dapatlah kita ketahui, bahwa di dalam tingkat kasasi tidak diperiksa tentang duduknya perkara atau faktanya tetapi tentang hukumnya, sehingga tentang terbukti tidaknya peristiwa tidak akan diperiksa. Penilaian mengenai hasil pembuktian tidak dapat dipertimbangkan dalam pemeriksaan tingkat kasasi. Mahkamah Agung terikat pada peristiwa yang telah diputuskan dalam tingkat terakhir. Jadi dalam tingkat kasasi peristiwanya tidak diperiksa kembali. Dengan

37 Lihat Pasal 46, 47 Undang-Undang No. 14 Tahun 1985 (Lembaran Negara Tahun 1985 Nomor 73 dan Tambahan Lembaran Negara Nomor 3316 Tahun 1985).

38 Sebagai contoh, permohonan kasasi diajukan langsung ke MA tidak dapat diterima (Putusan MA tanggal 10 Maret 1959 No.2 K/Kr/1959).

39 Beberapa contoh persyaratan formal yang jika tidak dipenuhi dapat mengakibatkan permohonan kasasi tidak diterima antara lain: permohonan diajukan oleh seorang kuasa tanpa kuasa khusus (putusan MA tanggal 11 September 1958 No.117 K/Kr/1958); permohonan kasasi dicap jempol tanpa pengesahan oleh pejabat berwenang (putusan MA tanggal 5 Desember 1961 No.137 K/Kr/1961).

40 Konsideran huruf b Peraturan Mahkamah Agung (PERMA) Nomor 1 Tahun 2001 tentang Permohonan Kasasi Perkara Perdata Yang Tidak Memenuhi Persyaratan Formal.

41 Pasal 1 huruf a Peraturan Mahkamah Agung (PERMA) Nomor 1 Tahun 2001 tentang Permohonan Kasasi Perkara Perdata Yang Tidak Memenuhi Persyaratan Formal.

42 Dalam Peraturan Mahkamah Agung (PERMA) Nomor 1 Tahun 2001 tersebut dijelaskan prosedur untuk tidak meneruskan permohonan kasai yang tidak memenuhi syarat formal, yakni Panitera membuat Surat Keterangan Kepaniteraan yang diketahui dan ikut menandatangani oleh Ketua Pengadilan Tingkat Pertama tempat permohonan diajukan (vide Pasal 2 ayat 1, 2, 3 Peraturan Mahkamah Agung (PERMA) Nomor 1 Tahun 2001).

43 Pasal 45A ayat (3) yang berbunyi “[...] permohonan kasasi yang tidak memenuhi syarat-syarat formal, dinyatakan tidak dapat diterima dengan penetapan ketua pengadilan tingkat pertama dan berkas perkaranya tidak dikirimkan ke Mahkamah Agung”. 
demikian Mahkamah Agung dalam tingkat kasasi bukan sebagai pengadilan judex factie.

Ketentukan di dalam Pasal 30 UndangUndang Nomor 14 Tahun 1985 Tentang Mahkamah Agung, yang telah diubah dengan Undang-Undang Nomor 5 Tahun 2004, sebagaimana selanjutnya telah diubah dengan Undang-Undang Nomor 3 Tahun 2009, mengatur tentang alasan-alasan yang dapat dijadikan dasar dalam pengajuan upaya hukum Kasasi. Dalam rangka pembatasan upaya hukum Kasasi, maka terkait dengan penerapan alasan-alasan untuk pengajuan upaya hukum kasasi diperlukan pembatasan keberlakuan ketentuan Pasal 30 Undang-Undang Nomor 14 Tahun 1985, adalah sebagai berikut, yaitu, alasan Kasasi pada poin:

a. Tidak berwenang atau melampaui batas wewenang

Perkara Kasasi yang diajukan dengan alasan sub a ini, sebenarnya relatif sangat sederhana dan sudah relatif pasti cara penafsiran hukumnya. Adapun yang dimaksud tidak berwenang disini adalah berkaitan dengan kompetensi relatif dan absolut pengadilan. Makna kompetensi absolut adalah kewenangan memeriksa dan mengadili perkara diantara Badan-badan Peradilan berdasarkan pada pembagian wewenang dan pembebanan tugas (yurisdiksi), sebagaimana ditentukan di dalam Pasal 18 Undang-Undang Nomor 48 Tahun 2009 tentang Kekuasaan Kehakiman, dibedakan menjadi 4 (empat) lingkungan badan peradilan, yakni; badan peradilan umum, badan peradilan agama, badan peradilan militer, dan badan peradilan tata usaha negara, yang masing-masing mempunyai kompetensi absolut. Adapun makna kompetensi relatif berkaitan dengan kewenangan mengadili/memeriksa perkara dari suatu Pengadilan Negeri berdasarkan pada pembagian daerah hukum (yurisdiksi). Dengan kata lain kompetensi relatif mengatur pembagian kekuasaan mengadili antar pengadilan yang serupa, tergantung dari tempat tinggal tergugat (vide Pasal 118 HIR).

Sedangkan yang dimaksud dengan melampaui batas wewenang bisa terjadi bila pengadilan mengabulkan gugatan dengan melanggar suatu asas menurut Pasal 178 ayat (2) dan (3), HIR jo. Pasal 189 ayat (2) dan (3) Rbg, bahwa: "Hakim wajib mengadili semua bagian tuntutan dan dilarang menjatuhkan putusan atas perkara yang tidak dituntut atau mengabulkan lebih daripada yang dituntut (melanggar asas ultra petita)".

Dengan demikian, nampak bahwa penggunaan alasan sub a. ini, sebenarnya relatif sangat sederhana dan sudah relatif pasti cara penafsiran hukumnya, disamping itu, sudah terdapat berbagai Yurisprudensi putusan Mahkamah Agung yang sejenis, sehingga semestinya ditentukan bahwa alasan sub a) ini menjadi kewenangan Hakim PN atau PT untuk menjatuhkan putusan akhir. Adapun beberapa Yurisprudensi putusan Mahkamah Agung yang kaidah hukumnya berkenaan dengan kewenangan Pengadilan Negeri adalah sebagai berikut:

1. Putusan MARI No. 162K/ Pdt/1992 tanggal 28 April 1994, kaidah hukumnya: Sengketa hak Milik berdasarkan pasal 50 Undang-Undang Nomor 7 Tahun 1989 tentang Peradilan Agama yang berwenang mengadili tentang sengketa tersebut adalah Peradilan Umum/Pengadilan Negeri. ${ }^{44}$

2. Putusan MARI No. $88 \mathrm{~K} /$ TUN/1993 tanggal 7 September 1994, kaidah hukumnya: Meskipun sengketa terjadi akibat dari surat keputusan pejabat tetapi perkara tersebut menyangkut pembuktian hak milik atas tanah, gugatan hatus diajukan terlebih dahulu ke pengadilan umum karena

44 Mahkamah Agung RI, 1995, Himpunan Putusan MARI tentang Kewenangan Mengadili, Mahkamah Agung RI dan the Asia Foundation, Jakarta, hlm. 3. 
merupakan sengketa perdata. ${ }^{45}$

3. Putusan Mahkamah Agung: tanggal 5-12-1973 No. $261 \mathrm{~K} /$ Sip/1973, kaidah hukumnya: Dalam hal ada lebih dari seorang tergugat masing. masing bertempat tinggal dalam wilayah Pengadilan Negeri yang berbeda-beda, menurut Pasal 118 H.I.R. penggugat dapat mengajukan di Pengadilan Negeri dimana salah seorang tergugat bertempat tinggal. ${ }^{46}$

b. Salah menerapkan atau melanggar hukum yang berlaku

Perkara Kasasi yang diajukan dengan alasan sub b ini saja yang dapat diterima sebagai alasan pengajuan Kasasi, dikarenakan Mahkamah Agung adalah bukan judex factie, dan hanya memeriksa ada tidaknya kesalahan penerapan hukum.

c. Lalai memenuhi syarat-syarat yang diwajibkan oleh peraturan perundangundangan yang mengancam kelalaian itu dengan batalnya putusan yang bersangkutan.

Perkara Kasasi yang diajukan dengan alasan sub c ini, dapat ditentukan bahwa alasan sub c ini sudah termasuk dalam kewenangan Mahkamah Agung pada sub b, yaitu, dalam rangka memeriksa ada tidaknya kesalahan penerapan hukum.

\section{Kesimpulan}

Berdasarkan keseluruhan uraian di atas, maka dapat ditarik simpulan, bahwa: Pertama, dalam rangka mewujudkan asas peradilan sederhana, cepat dan biaya ringan, serta mengurangi penumpukkan perkara di tingkat kasasi dapat dilakukan dengan cara pelembagaan dan pendayagunaan mediasi yang terintegrasi dengan proses berperkara di pengadilan berdasarkan ketentuan di dalam Peraturan Mahkamah Agung (Perma) Nomor 1 Tahun 2008 tentang Prosedur Mediasi Di Pengadilan. Kedua, dalam rangka pembatasan upaya hukum Kasasi dapat dilakukan dengan beberapa upaya diantaranya: Pembatasan Upaya Hukum melalui lembaga Mediasi di Pengadilan, dan Pembatasan Upaya Hukum melalui Alasan dan Syarat berdasarkan Ketentuan Undang-Undang Nomor 14 Tahun 1985.

\section{DAFTAR PUSTAKA}

\section{A. Buku}

Hutchinson, Terry, 2002, Resarching and Writing in Law, National Library of Australia, Sydney.

Kan, J. Van, dan J.H. Beekuis, 1983, Pengantar Ilmu Hukum (terjemahan Moh. O. Masdoeki), Cet. X, Pembangunan Ghalia Indonesia, Jakarta,. Martindale-Hubbell, 1999, International Arbitration and Dispute Resolution Directory, Cavendish Publishing Limited, London.

Marzuki, Peter Mahmud, 2005, Penelitian Hukum, Cet. I, Prenada Media, Jakarta.

Mahkamah Agung RI, 2004, Pedoman Pelaksanaan Tugas dan Administrasi Pengadilan, Buku II, Mahkamah Agung RI, Jakarta.
1995, Himpunan Putusan MARI tentang Kewenangan Mengadili, Hasil kerjasama Mahkamah Agung dengan the Asia Foundation, Jakarta.

Panggabean, Henry P., 2001, Fungsi Mahkamah Agung dalam Praktek Sehari-hari, Upaya Penanggulangan Tunggakan Perkara dalam Pemberdayaan Fungsi Pengawasan Mahkamah Agung, Sinar Harapan, Jakarta.

Poerwadarminta, 1989, Kamus Umum Bahasa Indonesia, Balai Pustaka, Jakarta.

Supomo, R., 1971, Hukum Atjara Perdata Pengadilan Negeri, Pradnja Paramita, Djakarta. 
B. Makalah

Hasibuan, Otto, "Problematik Mediasi dalam Praktek

Pengadilan Dihubungkan dengan Perma No.

1 Tahun 2008 tentang Prosedur Mediasi di Pengadilan", Makalah, disampaikan dalam Launching Magister Hukum Minat Studi Peradilan Fakultas Hukum Universitas Airlangga dan Sosialisasi Perma No. 1 Tahun
2008, Surabaya, 14 Februari 2004.

\section{Artikel Internet}

Harifin M. Tumpa, "Pembatasan Perkara Dimasukkan Revisi UUMA", http://www. id.berita.yahoo.com/harifin-pembatasanperkara-dimasukkan-revisi-uu-ma.html, diakses 3 Mei 2015. 